\title{
Griewe in Suid-Afrikaanse hospitale: 'n Geskiedkundig-verpleegkundige perspektief
}

\author{
S Potgieter \\ D Cur (Student) \\ Departement Verpleegkunde \\ RAU
}

\&

M Muller

D Cur

Departement Verpleegkunde RAU

\section{Summary}

The nursing service manager is accountable for adequate and efficient personnel management in the nursing service and the management of grievances is an important aspect of the personnel management function. The question arises, however, how and when grievances in nursing services arose and developed? The purpose of this article is to give a historical description of the development and management of grievances in nursing services for the time frame 1652-1990. An historical analysis was undertaken by means of news paper analysis, as well as other written resources. The results show that the development of grievances are related to the development of hospitals in South Africa and that grievances were poorly managed. The following conclusions are made:

* grievances in nursing are related to the establishment of hospitals;

* the first official grievance was lodged in 1824 by a surgeon:

* grievance are mainly related to the working conditions, remuneration and management;

* complaints with salaries and food were lodged by nurses as early as 1869

* it appears as if nursing service managers are not adequately skilled in the management of grievances experienced by nursing staff - the same mistakes are made leading to strike action by nurses/midwives;

* unhappiness with the inappropriate manner in which grievances are managed lead to industrial action by nursing staft since 1889 .

Continuous empowerment of nursing services managers in the management of grievances is important and therefore the development of a model for grievance management in nursing services is also recommended.

\section{'n Klagte word omskryf as 'n hoorbare uifing van liggaemlike of geestelike smart deur woorde of versugtinge. \\ 'n Orief word beskryf as 'n beswear feen lets wat seermeak of krenk, dus 'n rede vir ontevredenheid of misnoegdheid.}

\section{Oorsig Artikel}

\section{Uittreksel}

Die verpleegdiensbestuurder is aanspreeklik vir, onder andere, effektiewe personeelbestuur in die verpleegdiens en griewehantering vorm ' $n$ belangrike komponent van hierdie personeelbestuur. Die vraag ontstaan egter hoe en wanneer griewe in verpleegdienste ontstaan het. Die doel met hierdie artikel is om ' $n$ geskiedkundige beskrywing van die ontstaan en hantering van griewe in verpleegdienste te gee vir die tydperk 1652-1990. 'n Geskiedkundige ontleding is aan die hand van koerantanalises en ander geskrewe bronne onderneem. Die resultate toon dat griewe in verpleegdienste verband hou met die ontwikkeling van hospitale in Suid-Afrika en dat griewe nie toereikend hanteer is nie. Deurlopende en volgehoue bemagtiging van die verpleegdiensbestuurder in die hantering van griewe is belangrik en derhalwe word die ontwikkeling van 'n model vir griewehantering in verpleegdienste aanbeveel.

\section{Inleiding}

Gesondheidsdienste - en dus ook verpleging - in Suid-Afrika, het oor die afgelope eeue vanaf privaatversorging vir die hoërklas en tenthospitale vir die versorging van burgerlikes, tot ' $n$ hoogsgespesialiseerde diens en beroep ontwikkel. Hospitale het gegroei vanaf 20-bedtente tot tegnologiese reuse met groot hoeveelhede personeel. Hierdie ontwikkeling het noodwendig ' $n$ verandering in die verplegingspersoneel se werkverwante behoeftes en -frustrasiesmeegebring. Verpleegdiens- bestuur moes deurlopend aanpassings maak om personeeltevredenheid en personeelbehoud te kon handhaaf

Konflik en griewe is inherent aan enige verhouding tussen die werkgewer en werknemer - ook in verpleging. Verpleging en die verplegingsberoep vorm ' $n$ integrale en kardinale deel van die arbeidsterrein in Suid-Afrikaanse gesondheidsdienste. In die afgelope dekade het arbeidsonrus en politieke aspekte ingrypende veranderinge teweeg gebring wat die korrekte hantering van griewe en 
dissiplinêre prosedures in gesondheidsdienste noodsaak.

Klagtes en griewe moet van mekaar onderskei word. 'n Klagte word in die verklarende woordeboek omskry' as 'n hoorbare uiting van liggaamlike of geestelike smart deur woorde of versugtinge (HAT, 1988: 558). 'n Grief daarenteen - word beskryf as 'n beswaar teen iets wat seermaak of krenk, dus 'n rede vir ontevredenheid of misnoegdheid (HAT, 1988: 320), veral wanneer diensvoorwaardes nie nagekom word nie en die praktisyn se regte geskend word.

Ontevredenheid onder werknemers spruit gewooniik voort uit werksomstandighede of persoonlike ervarings in die werksomgewing. Om personeeltevredenheid te verseker, behoort bestuurders goeie arbeidsverhoudinge te handhaaf en klagtes te hanteer voordat dit in formele griewe verander of ernstige werks- of wetiike probleme veroorsaak (Denton \& Boyd, 1990: 1). Hierdie outeurs meld verder die noodsaaklikheid dat klagtes en nie-verbale manifestasies daarvan, soos hoë afwesigheidsyters en swak gehaltewerk, vroegtydig herken moet word en die ware redes vasgestel moet word. Om klagtes effektief te kan ondersoek is dit noodsaaklik dat bestuur die werkers ken en begrip het vir hul taak en verantwoordelikheid, sowel as vir hul persoonlike behoeftes en omstandighede. Reëls moet verduidelik word aan werknemers en indien nodig, herhaal word en beleids- en prosedurehandleidings moet beskikbaar en toeganklik wees (Denton \& Boyd, 1990: 3-10).

Alle klagtes moet so spoedig moontlik ondersoek word. Vinnige optrede na aanleiding van klagtes voorkom nie slegs dat die klagtes in amptelike griewe ontaard nie, maar verhoog die geloofwaardigheid van die bestuurder by personeel en verbeter die algemene werksklimaat in die gesondheidsdiens. Die verpleegdiensbestuurder is nie net aanspreeklik vir gehalteverpleging in die verpleegdiens nie, maar ook vir gehaltepersoneelbestuur van verplegingspersoneel om sodoende ' $n$ hoë gehaltewerklewe te fasiliteer.

Die doel met hierdie artikel is om ' $n$ eenvoudige geskiedkundige beskrywing te gee van die ontstaan van griewe in verpleegdienste, asook die hantering

\section{Ontevredenheid onder} werknemers spruit gewoonlik voort uit werksomstandighede of persoonlike ervarings in die werksomgewing.

\section{Navorsingsontwerp en Navorsingsmetodes}

'n Geskiedkundige ontleding met betrekking tot die ontstaan en ontwikkeling van griewe in Suid-Afrikaanse verpleegdienste, asook die hantering daarvan, is vir die tydperk 1652 tot 1990 by wyse van ' $n$ koerantanalise en 'n geskiedkundige literatuuranalise uitgevoer. Die geldigheid en betroubaarheid van geskiedkundige navorsing is verwant aan die bronne waaruit die data geneem is. In hierdie studie is primêre bronne gebruik, naamlik koerantberigte, asook 'n verpleegkundige geskiedenishandboek wat as ' $n$ sekondêre bron geklas-sifiseer word. Betroubaarheid is gekontroleer deur ' $n$ arbeidsbetrekkingekonsultant as onafhanklike navorser te benut om enkele koerantstudieontledings te doen en met die navorser te kontroleer. Inter-subjektiewe dialoogvoering is gebruik - tydens ' $n$ paneelbespreking is die ontledings en interpretasies deur die navorser en konsultant gekontroleer en betroubaarheid ('n hoë mate van ooreenstemming) is bevestig. Vooroordeel deur beriggewers is uitgeskakel deur slegs koerantberigte te benut waar dieselfde berig oor die navorsings-onderwerp in drie of meer koerante gepubliseer is. Daar is verder gepoog om woorde binne die kontekstuele geskiedkundige verband oor die verskillende tydperke te behou.

Sydigheid is verder uitgeskakel deur mildelik gebruik te maak van direkte aanhalings en om die verskillende koerante en publikasies - vanuit alle ideologiese voorkeure - in te sluit. Alle beskikbare koerantberigte is per mikrofische geraadpleeg. Die frekwensie van koerantberigte oor ' $n$ onderwerp, blyk steeds die enigste kriterium vir geldigheid te wees (Scott, 1990:148). Verifiëring van resultate deur die deskundige is noukeurig uitgevoer.

'n Doelgerigte seleksie van koerantberigte en ander publikasies oor die navorsingsonderwerp is gedoen. ' $n$ INGEN-indeks is vanaf Bloemfontein aangevra. Alle koerantberigte beskikbaar op mikrofische en/of film sedert 1900 , asook ander toepaslike literatuur, is doelgerig nagegaan om die teenwoordigheid van griewe in verpleging te identifiseer. Die klem het geval op berigte wat oor griewe van verpleegsters gehandel en en/of insidente wat op verpleging gekofus het en moontlik aan 'n grief gekoppel kon word. Engels, sowel as Afrikaanstalige nasionale persgroepe is gebruik ten einde verteenwoordigendheid te verseker.
Alle berigte, asook relevante literatuur, is stelselmatig deurgegaan en afskrifte is gemaak van artikels wat geidentifiseer is. Hierdie berigte is daarna weer bestudeer en woorde en temas is uitgelig, volgens die beginsels van inhoudsontleding soos deur Burns en Grove (1987: 97-104) aanbeveel. Woorde wat geidentifiseer is, was "hospitale, verpleegsters / verpleegkundiges, stakings, griewe en gesondheidsdienste." Hierdie berigte is vervolgens gekruiskontroleer in die verskillende koerante en daarna in kronologiese volgorde volgens datums gerangskik.

\section{Resultate}

\section{Steekproefrealisasie}

Vyf honderd berigte uit vyf hoofkoerantgroepe is benut in die studie, asook Searle (1965) se geskiedkundige boek oor verpleging. Vier maande is aan die deurlees en ontleding van hierdie berigte spandeer.

\section{Klassifisering van resultate}

Die resultate word soos volg weergegee, met toepaslike verbandlegging:

* Die geskiedkundige beskrywing van griewe in verpleging: ' $n$ inleiding.

* Bespreking van griewe en klagtes om die onderskeid aan te dui.

* Geskiedkundige verloop.

* Die ontwikkeling van hospitale

* Arbeidsonrus in verpleegdienste.

Geskiedkundige beskrywing van griewe in verpleging:

\section{'n Inleiding}

Konflik en griewe is inherent aan enige verhouding tussen werkgewer en werknemer. Daar sou dus afgelei kon word dat daar reeds vir eeue griewe in verpleging bestaan. Verpleging en die verplegingsberoep vorm ' $n$ integrale en kardinale deel van die arbeidsterrein in Suid-Afrikaanse gesondheidsdienste. Arbeidsonrus en politieke aspekte het omvattende veranderinge in die land teweeggebring. Veral in die afgelope dekade het ingrypende veranderinge ingetree wat die korrekte hantering van griewe en dissiplinêre prosedures in gesondheidsdienste noodsaak. Die verpleegdiensbestuurder is verantwoordelik vir die vinnige en toereikende hantering van griewe wat deur die verpleegpersoneel envar word.

Die formalisering van grieweprosedures in verpleegdienste hou verband met die ontwikkeling en vooruitgang van hospitale en gesondheidsdienste in SuidAfrika. Die verloop van arbeids verhoudinge in die gesondheidsdienste asook gepaardgaande stakings deur 
verpleegpersoneel as gevolg van onopgeloste griewe, het ook hierdie formalisering beinvloed. Hiermee saam het eksterne organisasies, byvoorbeeld vakbonde en die Suid-Afrikaanse Verpleegstersvereniging (SAW) betekenisvolle rolle gespeel. Die dinamika van die politiek en derhalwe politisering van gesondheidsdienste, kan egter nie verontagsaam word nie. Die begrippe "griewe" en "klagtes" asook enkele beginsels sal nou bespreek word.

\section{Bespreking van griewe en klagtes}

In enige werksomgewing is daar wisselwerking tussen verskillende individue en groepe. Omdat hierdie groepe en individue teenstrydige doelwitte mag nastreef, is dit byna onmoontlik om te verhoed dat daar ontevredenheid of klagtes sal voorkom. Klagtes en griewe moet van mekaar onderskei word. 'n Klagte word in die verklarende woordeboek omskryf as ' $n$ hoorbare uiting van liggaamlike of geestelike smart deur woorde of versugtinge (HAT, 1988:558). 'n Grief daarenteen - word omskryf as 'n beswaar teen iets wat seermaak of krenk, dus 'n rede vir ontevredenheid of misnoegdheid (HAT, 1988:320).

Ontevredenheid onder werknemers spruit gewoonlik voort uit werksomstandighede of persoonlike ervarings in die werksomgewing. Laasgenoemde hou verband met persoonlike verhoudings. Om personeeltevredenheid te verseker, behoort bestuurders goeie arbeidsverhoudinge te handhaaf en klagtes te hanteer voordat dit in formele griewe verander of ernstige werks- of wetlike probleme veroorsaak (Denton \& Boyd, 1990:1).

Nie alle klagtes is noodwendig negatief nie, dit is dikwels slegs die natuurlike gevolg van die interaksie tussen bestuur en personeel. Tog sien bestuur dit dikwels as 'n aanduiding van hulle sogenaamde swak bestuursvernuf of vaardighede. Volgens Denton en Boyd $(1990: 3-7)$ is dit noodsaaklik dat klagtes deur die bestuur erken moet word, selfs ook die nie-verbale klagtes of manifestasies soos byvoorbeeld hoë afwesigheidsyfers en swak werkgehalte. Die werklike rede vir die klagte behoort vasgestel te word aangesien die rede wat aangevoer word, dikwels nie die ware rede is nie.

Om die klagtes werklik effektief te kan ondersoek, is dit noodsaaklik dat bestuur die werkers ken en begryp. Daar moet begrip wees vir hul taak en verantwoordelikheid, asook vir hulle persoonlike behoeftes en omstandighede. Bestuur moet hulself ook in die posisie van die personeellid kan plaas om ' $n$ perspektief van die betrokke persoon se siening te kry. Selfs indien die bestuur ' $n$ probleem as nietig beskou, is dit noodsaaklik dat dit met erns bejeën moet word en dat die werknemer tevrede met die hantering daarvan moet wees. Reëls moet vooraf aan alle werknemers verduidelik word en indien nodig. periodiek herhaal word. Beleids- en prosedurehandleidings moet vir elke werknemer beskikbaar en toeganklik wees (Denton \& Boyd, 1990:10).

Alle klagtes moet so spoedig as moontlik ondersoek word. Die vlak van die ondersoek sal van die erns van die klag afhang. Die besluit moet ook so gou doenlik aan die werknemer oorgedra en verduidelik word. Wanneer dit nie moontlik is om die uitslag van die ondersoek onmiddellik aan die werknemer bekend te maak nie, moet die besluit en rede daarvoor verstrek word. Vinnige optrede na aanleiding van klagtes, voorkom nie slegs dat die klagtes in amptelike griewe ontaard nie, maar verhoog die geloofwaardigheid van die bestuurder by personeel en verbeter die algemene werksklimaat (Denton \& Boyd, 1990:8-12).

\section{Geskiedkundige verloop}

Dit kan aanvaar word dat by slawe wat die versorging van siekes in private huishoudings waargeneem het, ook ontevredenheid bestaan het. Die formalisering van griewe en die ontwikkeling van grieweprosedures in verpleegdienste hou egter verband met die ontwikkeling van hospitale in SuidAfrika. Die verpleegkundige het in status verander vanaf onafhanklike werker (byvoorbeeld vroedvrou) na indiensgenome hospitaalpersoneel. Hierdie geskiedkundige analise is by wyse van 'n literatuurstudie en koerantberigte verken en word kronologies weergegee. Die invloed van eksterne organisasies op die ontwikkeling van die beginsels van griewehantering in verpleging, word ook kortliks beskou.

\section{Die ontwikkeling van hospitale}

Die doel met die stigting van ' $n$ nedersetting aan die Kaap deur die Verenigde Oost-Indische Compagnie was die totstandbringing van ' $n$ verversingspos en hospitaal. Daar moes voorsiening gemaak word vir die talle siek matrose en amptenare van die Kompanjie op hul reise na Batavia. Reeds in 1627 het skepe op pad van Holland na Indië by die Kaap aangedoen en ' $n$ tydelike tenthospitaal is op/ingerig om 100 siek bemanningslede die kans te gee om eers te herstel. Hierdie maatreël het tot 'n sterftesyfer van slegs 44 man gelei en die gedagte aan 'n permanente nedersetting het ontstaan (Searle, 1965:20).

Johann van Riebeeck, 'n chirurg, is as Kommandeur van die Kaap aangestel, vanweë sy uitgebreide kennis van medies-sosiale probleme, asook kennis van die handelsmetodes van die Kompanjie. Slegs ' $n$ maand na hul aankoms aan die Kaap in Mei 1652, is die eerste siek matrose deur twee skepe aan wal gebring en die oprigting van tenthospitale het onmiddellik begin. Die eerste verpleegaksies of versorging was dus daardie waar soldate of ondergeskikte lede van die nedersetting siek matrose in die tenthospitale verpleeg of versorg het. Hoë amptenare is nie in die tenthospitale nie, maar in hul huise versorg (Searle, 1965:22).

In 1656 word die eerste permanente hospitaal, wat 20-30 pasiënte kan huisves, voltooi. Dit is duidelik dat goeie bestuur ' $n$ prioriteit was, aangesien Van Riebeeck drie bestuurders aangestel het. Die spesifieke taak van een van die bestuurders was om toe te sien dat die werkers nie slenter of hulle siek voordien nie (Searle, 1965:28). Dit mag gesien word as die eerste vorm van beheer of dissipline in hospitale en was dus die voorloper van personeelbestuur deur verpleegdiensbestuurders.

Veertig jaar het die hospitaal in die behoeftes aan gesondheidsorg voldoen. Die stygende getal siek matrose wat aan wal gebring is, asook swak toestande wat siektes onder die slawe laat toeneem het, het die vraag na groter en beter hospitaalfasiliteite laat ontstaan. In 1699 word 'n tweede hospitaal, wat 400 pasiënte kon huisves, voltooi. Die vraag het steeds die aanbod oorskry en oorvol hospitale, tydelike geboue en massa-opnames van verswakte pasiënte het mediese en verpleegsorg bemoeilik. Alhoewel daar geen inskrywings gevind is nie, kan aangeneem word dat hierdie toestande tot ontevredenheid en moontlike griewe onder die versorgers gelei het (Searle, 1965:40-46)

Daar is reeds vroeg op goeie toesig vir hoër produktiwiteit staatgemaak. Die

\section{Nie alle klagtes is noodwendig negatief nie, dit is dikwels slegs die natuurlike gevolg van die interaksie tussen bestuur en personeel.}


eerste matrone wat in 1700 aangestel is, moes onder andere toesig hou oor die slawe wat met die versorging van pasiënte gemoeid was (Searle, 1965: 49). Omdat wins die hoofmotief van die Kompanjie was, het pasiënte wat te lank gehospitaliseer was, sowel as diegene wat gesterf het, ' $n$ verlies beteken. Die matrone se handhawing van dissipline in die hospitale was dus van deurslaggewende belang om sogenaamde effektiewe sorg te verseker.

Die eerste amptelike grief oor personeeltekorte en ' $n$ gebrek aan gesag is in 1824 van die inwonende chirurg van die Somerset-hospitaal ontvang. Hy het gekla dat hy nie met die regulasies bekend was nie, nie oor die nodige gesag oor bediendes beskik het nie en ook nie voldoende onderge-skiktes gehad het om die pligte uit te voer nie (Searle, 1965: 67,68).

$\mathrm{Na}$ die tweede Britse besetting van die Kaap in 1806 het die Hollandssprekende setlaars na die binneland getrek. Die ontdekking van diamante in 1867 en goud in 1883 het daartoe gelei dat dorpe byna oornag ontstaan het. Die instroming van mense het gesondheidsprobleme soos malaria, longontsteking en ingewandskoors laat toeneem en die behoefte aan geriewe vir die versorging van siekes het gestyg (Searle, 1965:70). Statistieke toon dat teen die einde van die negentiende eeu, daar 3005 beddens in hospitale in Suid-Afrika beskikbaar was. Hierdie groei in gesondheids-dienste, tesame met tegnologiese ontwikkeling, het die vaardighede wat verpleegsters benodig het om verpleegsorg van gehalte te kon verleen, ingrypend verander. Die behoefte aan 'n opgeleide, vaardige en stabiele werkmag van verpleegsters het ontstaan. Werkertevredenheid was reeds op daardie tydstip belangrik om sodoende die omset van kundige verpleegsters te beperk en dus die gehalte van verpleegsorg te handhaaf (NUA 100-L, 1992:18).

\section{Arbeidsonrus in verpleegdienste}

Aanduidings in die literatuur toon dat arbeidsonrus of -ontevredenheid in verpleeggeledere nie ' $n$ nuutjie is nie. Deur die eeue heen het verpleegsters ook nie geskroom om hulle ontevredenheid rakende werktoestande bekend te maak nie. 'n Groep saaloppassers van die Somerset-hospitaal het reeds in 1869 'n versoekskrif aan die regering gerig om vir hoër salarisse te beding. Hulle het die volgende omtrent hulle werksomstandighede vermeld, naamlik dat "hul pligte van 'n moeilike aard is en dag en nag hul onverfloude waaksaamheid vereis en dat die gesondheid en selfs die lewe dikwels in gevaar gestel word". Bowendien het hulle klagtes oor die kos in die verpleegsterskwartiere gehad. Dit het daartoe gelei dat die inwonende chirurg, dr. Parsons, in ' $n$ brief aan die koloniale sekretaris skryf: "Dit is raadsaam om reëlings te tref vir ' $n$ beter stelsel van dieet as diè wat tans bedien word." Hy meld dat daar reeds vier of vyf verpleegsters as gevolg van die toestande bedank het (Searle, 1965:87).

Die eerste "staking" wat deur 'n grief ontlok is, was waarskynlik in 1889 . In Februarie 1889 het die Raad van die hospitaal in Pretoria die matrone (mej. Paget) drie maande kennis gegee op grond daarvan dat "zij de Hollendsche taal niet magtig was." Mej. Paget en haar totale personeel het uitgestap. Dit kan staan om 'n liggaam daar te stel om die regte van verpleegsters te beskerm en standaarde vir die beroep te hanhaaf. Die uitbuiting van verpleegkundiges in die vakleerlingstelsel, die verdeeldheid in verpleeggeledere na die Suid-Afrikaanse oorlog en die afwesigheid van SuidAfrikaanse verpleeglui in topbestuursposte, het die behoefte aan so ' $n$ organisasie versterk. As gevolg van hierdie gevoel onder verpleegkundiges is die "South African Trained Nurses' Association" (SATNA) gestig (Searle, 1965:245). As ' $n$ beroepsorganisasie kon SATNA verpleegkundiges verenig en druk uitoefen om billike arbeidspraktyke te bevorder. Hierdie is die eerste aanduiding vanuit die beroep van ' $n$ organisasie wat hom sou bemoei met onder andere die griewe wat in die professie ontstaan het.
Om die klagtes werklik effektief te kan ondersoek, is dit noodsaaklik dat bestuur die werkers ken en egryp. Daar moet begrip wees vir hul taak en verantwoordelikheid, asook vir hulle persoonlike behoeftes en omstandighede.

as 'n vorm van industriële aksie beskou word. Sy was gegrief oor die onregverdige behandeling, en het daarom haar arbeid onttrek. Die optrede van medepersoneel het uit simpatie met die gegriefde gespruit (Searle, 1965:88).

Searle (1965:90) meld ook dat ' $n$ groot groep verpleegkundiges in 1890 ineengestort het, as gevolg van groot werkdruk en lang diensure (soms tot 20 ure per dag). Dit is dus duidelik dat die werksomstandighede van verpleegkundiges in die negentiende eeu van so ' $n$ aard was dat griewe wel kon ontstaan. Die Kaapkolonie se "Medicine and Pharmacy Act" (Wet 34 van 1891) word in 1891 aangeneem. Dit maak voorsiening vir staatsregistrasie van verpleegsters en vroedvroue en vir beheer oor die beroep. Hierdie mylpaal impliseer ook beskerming aan pasiënte, omdat ' $n$ verpleegster nou op grond van wangedrag professioneel-eties gedissiplineer kon word (NUA 100-L, 1992:18). Alhoewel pasiënte hierdeur van die gehalte van die verpleging verseker is, was daar geen aanduidings van beter kanale vir verpleegkundiges om hulle griewe te kon lug nie.

Verpleegkundiges in die beroep het gevoel dat dit nodig was om ook hulle regte te beskerm en het hulle daarvoor beywer. in 1914 het die behoefte ont-
Die sukses van SATNA word bevraagteken wanneer aangedui word dat daar in 1942 ' $n$ poging deur die "General Workers Union" geloods is om verpleegsters in 'n vakbond te organiseer. Die stelling moet gesien word teen die agtergrond van die politisering van gesondheidsdienste van die tyd. Die situasie wat in 1942 ontstaan het, het hom dus in 1990 herhaal. Dit was hoofsaaklik die gevolg van ontevredenheid wat gespruit het uit die uitbuiting van verpleegsters deur werkgewers. Dieselfde aspek was een van die be-weegredes vir die stigting van SATNA in 1914 en daar kan slegs gespekuleer word dat die verpleeg. kundiges dus nie tevrede was met die wyse waaop SATNA hierdie aspek hanteer het nie. Die poging tot organisering van verpleegsters in ' $n$ vakbond is deur SATNA suksesvol teengestaan. Die Wet op Verpleegsters, Nr. 45 van 1944, is as gevolg van SATNA se poging om die bestuur van die beroep binne die beroep te behou, aangeneem. Twee statutêre liggame, naamlik die SuidAfrikaanse Verpleegsters-vereniging (SAVV) en die Suid-Afrikaanse Verpleegstersraad (SAVR) se ontstaan is gesetel in die wet. Die sorgwekkende toestand waarin die verpleeg-dienste verkeer het, het daartoe gelei dat die regering van die dag voorsiening gemaak het vir verpligte lidmaatskap van alle verpleegkundiges van die SAW (Searle, 1965:234-237). Hierdie stap sou beteken dat die beroep van "n "closed shop" beginsel gebruik maak en dat slegs die SAW namens die beroep kon beding of griewe vir lede van die beroep op ' $n$ eksterne vlak kon hanteer. $\mathrm{Na}$ die implementering van die aanbevelings van die Wiehahn-komissie was lede weer vry om by ' $n$ geregistreerde vakbond aan te sluit. 
Studentverpleegsters van die Victoriahospitaal in Lovedale neem in 1949 aan 'n "simpatiestaking" deel. Na hul mening is ' $n$ kollega onregverdiglik geskors na deelname aan 'n petisie om oor sekere aspekte van die hospitaal te kla (Critical Health, 1988:54). Ouers het ingegryp en namens die studente voorstelle aan die Hospitaalraad gemaak. Daarna het die verpleegsters weer voortgegaan met hul werk. Later in dieselfde jaar het ' $n$ tweede krisis opgeduik omdat verpleegsters geweier het om godsdienstige vergaderings by te woon. As gevolg van hierdie voorvalle het die superintendent die hospitaal as opleidingshospitaal vir verpleegsters gesluit.

In 1958 vereis die regering dat alle swart verpleegsters oor pasboeknommers moet beskik alvorens hulle as verpleegsters kan registreer en verdere kursusse kan volg. Die "Federation of South African Women" en die "African National Congress" (ANC) se "Women's League" het die verpligte pasboek vir vroue teengestaan en 'n protesaksie georganiseer. Meer as tweehonderd (200) vroue het die vergadering te Baragwanath. hospitaal bygewoon. Dit toon die verpleegkundiges se ontevredenheid en openlike verset teen eksterne maatreëls wat verpleging en verpleegopleiding beinvloed.

Die verskynsel moet ook gesien word teen die sosio-polities-ekonomiese agtergrond van die status van die swart vrou in Afrika. Die swart verpleegster het die verpleegberoep benut om haarself op 'n hoër sosio-ekonomiese posisie te plaas, en was van die leiers in hul gemeenskap. In 1960 ondersteun verpleegkundiges swart ongeskoolde hospitaalwerkers tydens 'n "staking" by die Karl Bremer-hospitaal wat oor beter lone en werksom-standighede gehandel het (Critical Health, 1988:50-65). Hierdie is ' $n$ aanduiding van die invloed wat onopgeloste griewe van nieprofessionele werkers op die gedrag van verpleegkundiges kan hê.

In 1961 word "n "staking" by die King George Tuberkulose-hospitaal deur die "Hospital Workers Union" georganiseer om protes aan te teken teen ' $n$ insident waar ' $n$ matrone lytstraf op verpleegsters toegepas het. Geskoolde en ongeskoolde werkers het die eis dat die matrone afgedank moes word, ondersteun. Verdere eise het ingesluit gelyke eetgeriewe, 'n beter gehalte kos, die stigting van ' $n$ werknemersversekeringsfonds en ' $n$ einde aan rassediskriminasie in hospitaaldienste. Meer as 300 werkers het aan die tweeweeklange staking deelgeneem. Die gebied is deur die polisie afgekamp en die gemeenskap het die stakers van voedsel voorsien. Die staking het internasionale aandag geniet. Aan sommige eise is voldoen maar 21 van die stakers is afgedank (Critical Health, 1988:55). Uit die sekondêre griewe oor afgelei word dat politiek hier 'n rol kon gespeel het.

In Suid-Afrika was die vroeë sestigerjare deur swart politieke opstande gekenmerk en die verpleegdienste was was ook ingesluit. Verpleging en gesondheidsdienste speel ' $n$ belangrike rol in die SuidAfrikaanse samelewing. Dit is dus onvermydelik dat ontwikkelinge op die ekonomiese, politieke, sosiale en ander gebiede ' $n$ invloed op verpleging sal hê. Die politieke invloed is nie as aparte komponent deur die navorser ondersoek nie, maar dit is onvermydelik dat die invloed daarvan soms weerspieël word. Die politieke stelsel as eksterne invloed gelyke geriewe en rassediskriminasie kan

griewehantering op saal- of eenheidsvlak beinvloed, aangesien griewe rakende salarisse nie op eenheidsvlak aangespreek kan word nie. Verpleegdiensbestuurders wat griewe omtrent hierdie aangeleenthede ontvang het, sou dit dus nie kon hanteer nie, en indien die korrekte metode van verwysing na hoër gesag nie gevolg is en die nodige terugvoer nie aan die gegriefdes gegee is nie, kon hulle onder die indruk kom dat griewe geignoreer is. As gevolg van die kommunikasiekanale wat gevolg moet word, neem die oplos van griewe noodwendig lank. Dit mag tot frustrasies aanleiding gee wanneer ' $n$ tyd verloop om die probleem aan te spreek. Swak werkstoestande word ook onder die vergrootglas geplaas. Die "Race Relations Survey" (SAIRR, 1982:409) dui dit as moontlike oorsaak aan vir die groeiende tekorte in verpleegpersoneel in al die provinsiale hospitale in die land. 'n Kardio-chirurg van die Grootte Schuurhospitaal beweer volgens die verslag dat verpleegsters nie veel beter as slawe behandel word in terme van werksure, salaris en werks-voorwaardes nie. Hy wys ook verder daarop dat langtermyn beroepsgeleenthede vir verpleegkundiges baie beperk is. Dit mag daartoe lei dat persone met potensiaal wat 'n behoefte aan groei het, die verpleegberoep verlaat.

op die werksomstandighede van verpleegsters, word deur die volgende aanhaling uit die "Race Relations Survey" bevestig (SAIRR, 1982:410): "Many black nurses were unemployed although there were enough jobs to go around, work that was available was for white nurses only. There had been ' $n$ 'brain drain' in this sector to such an extent that hundreds of beds and many wards had been closed. Another problem was that many African nurses from homelands that had accepted independence were being categorised as 'foreign'. This meant they could not be registered with the South African Nursing Council, and consequently they had difficulty in finding work." Daar is aangevoer dat "the employment of black nurses in white hospitals would enable the state to reopen facilities and run them at a lower cost. This was because there were considerable differences between salaries of black nurses and white nurses." Alhoewel die verslag dit so stel, is die feit dat daar vakatures en leë beddens in blanke hospitale was, nie noodwendig hieraan toe te skryf nie, maar kon moontlik die gevolg wees van oorbeplanning vir blanke dienste.

Hierdie rasse-ongelykhede in verpleging was moontlik ook ' $n$ beinvloedingskrag op die griewe wat deur verskillende verpleegsters ondervind is. Dit kon selfs
Die voorafgaande word bevestig deur die bevindings van ' $n$ geneesheer wat ' $n$ ondersoek na die finansiële stand van verpleegkundiges ingestel het, naamlik dat - inflasie in aggenome - die finansiële status van verpleegsters in 1981 slegter was as in 1971. Die bedinginsmag van die SAVV vir beter salarisse in die verpleegberoep word bevraagteken. Die geneesheer wat die studie gedoen het, wys daarop dat die SAW nie by magte is om vir beter salarisse te beding nie, aangesien "the Board members of the Association were employed by the provincial authorities and were therefore unable to make realistic salary demands" (SAIRR Race Relations Survey, 1982:409). Hier word nie slegs die potensiële bron van griewe met betrekking tot finansiële aspekte van verpleging uitgelig nie, maar dit word ook betwyel of die amptelike liggaam in staat is om te beding, omdat die lede deel van die hiërargie van die provinsiale hospitale uitmaak. Dit is egter die amptenary van die SAVV wat onderhandel en nie die verkose lede van die Bestuur nie. Dit is 'n aspek waaroor steeds baie onkunde bestaan.

In 1982 vind ' $n$ protesboikot van die kantienfasiliteite by die Baragwanathhospitaal plaas. Laasgenoemde het ontstaan as gevolg van griewe oor onder 
andere die feit dat verpleeg-personeel geen kontrakte ter beskerming van hulself gehad het nie, geen vergoeding vir oortyd betaal is nie asook die swak gehalte van die kos (Critical Health, 1988:57). Soortgelyke boikotte wat teen die ghalte van die kos gemik was, het in dieselfde jaar in die Hillbrow-en Coronation-hospitale plaasgevind. Wanneer daar in ag geneem word dat protes reeds sedert die agtiende eeu aangeteken is oor die gehalte van kos in hospitale, laat dit onwillekeurig die vraag ontstaan of die aspek moontlik nie volledig ondersoek en opgelos is nie, en of hierdie dalk slegs ' $n$ sigbare vorm van protes verteenwoordig om ander griewe onder die bestuur se aandag te bring

Die afdanking van agthonderd werkers en negehonderd student-verpleegsters na ' $n$ weeklange staking by die Baragwanath-hospitaal in 1985, verteenwoordig ' $n$ dramatiese verandering in die siening van die verantwoordelikheid van die verpleegdiensbestuurder met betrekking tot griewehantering. Nadat daar nie aan hulle griewe gehoor gegee is nie, het die studente "gestaak" en is hulle afgedank. Dit was bekend dat hospitaal-skoonmakers, bodes, portiere, kombuispersoneel en verpleegassistente reeds die vorige jaar probeer beding het vir ' $n$ verhoging in lone en salarisse. Tydens ' $n$ massavergadering is hulle meegedeel dat verhogings eers in Maart 1986 oorweeg sou word. Kort na die vergadering het sommige van die daagliks betaalde werkers die kombuise en eetsale binnegegaan en kos op die vloere gegooi en breekware gebreek. Die maandelikse inkomste van sommiges was so min as R110 per maand (Star 85.11.26:12).

Die afdanking van die verpleegsters het gelei tot ' $n$ hooggeregshofsaak wat deur drie van die studentverpleegsters teen die Transvaalse Provinsiale Administrasie aanhanging gemaak is. Regter Justice Goldstein het bevind dat die afdanking onwettig was en dat alle studente herindiens geneem moes word. Die Citizen (85.11.26:3) het soos volg berig: "The judge said in dismissing the students en mass, the hospital authorities had ignored the rule of natural justice. He said the workers should have had their grievances individually heard. Mr Justice Goldstein said the hospital authorities had the onus of paying proper heed to the grievances of their employees". Oor dieselfde insident het die Star (85.11.26:12) soos volg berig: "they (hospital authorities) must heed the judge's wisdom that while strikes cannot be tolerated, there should be a workable

mechanism for expressing grievances and that, in micrcosm, is what South Africa's troubles are all about: communication." 'n Konsultant in Nywerheidsverhoudinge is deur die Sowetan (85.11.28:38) aangehaal toe hy die afwesigheid van strukture vir die hantering van griewe bespreek het: "Mr. Stewardt Pennington commented that many managements made the mistake of failing to establish structures for the settlement of grievances. The benefits of a structure which allows people to air their grievances are well known. If it is accepted that there is always going to be conflict between managers and employees, structures to deal with those conflicts and problems when they arise, can only improve the ability of managers to manage conflict. Public sector employees have adopted a very conservative view of the new industrial relations dispensation. Essentially the relationship which exists in the private sector between management and employees is no

\section{In belang van doeltreffende} konflikhantering is dit noodsaaklik dat verpleegbestuur 'n effektiewe meganisme sal skep waardeur griewe van verpleeglui bekend gemaak kan word.

\section{different to that in the public sector."}

In belang van doeltreffende konflikhantering is dit noodsaaklik dat verpleegbestuur 'n effektiewe meganisme sal skep waardeur griewe van verpleeglui bekend gemaak kan word. Die verpleegdiensbestuurder het verder ook ' $n$ verantwoordelikheid om toe te sien dat elke werker as individu die kans gegun word om sy saak te stel wanneer oortredings begaan is.

Griewehangering en die bekendmaking van griewe deur personeel is ' $n$ belangrike aspek van opwaartse kommunikasie in 'n organisasie. ' $n$ Geneesheer beklemtoon die belang van hierdie kommunikasie vanaf die werknemers na bestuur en meld dat wanneer onopgeloste griewe lei tot "stakings", vertroue en die beeld van 'n organisasie in die openbare sektor ernstig daardeur geskaad kan word. In 'n artikel wat onder die titel "Analysing the anatomy of a hospital strike" in die Star (85.11.29:16) verskyn het, wys hy daarop dat die sluiting van openbare hospitale nie die staat verarm nie, maar die administrasie in die verleentheid stel. "Thus in the case of public hospital strikes, the contest between employer and employee has nothing to do with profit and loss, but has everything to do with communication, with "face", and with "image" ${ }^{n}$. Volgens die geneesheer ontlok griewe rakende salarisse nie soveel simpatie by die publiek, wat in elk geval ook hoër salarisse sou wou ontvang, soos griewe rakende werksomstandighede nie. Die verpleegdiensbestuurder in die hospitaal is ' $n$ eerstevlakbestuurder en behoort dus kennis te dra van die omstandighede in die werksituasie wat moontlik aanleiding tot griewe kan gee. Daar kan gemeld word dat die "verleenthede" ook veroorsaak of vererger word deur die verdeelde beleidmakende en beheerprosesse tussen Hoofkantoor en hospitale. Hospitaalbestuur word blameer, maar hul het nie die bevoegdheid/beheer oor baie van die bestuurshandelinge nie. Dit mag egter nooit voorgehou word as rede waarom griewe geïgnoreer word nie.

In 1987 het sowat 400 studentverpleegsters van die Thembisa-hospitaal aan ' $n$ "staking" deelgeneem om teen swak kos en diskriminasie te protesteer. Die verpleegsters het aangevoer dat hulle deur hospitaalsekuriteitpersonee geïntimideer en lastig geval is. Hulle het ook beweer dat die hospitaaladministrasie rassistiese praktyke gevoer het. Die superintendent het ' $n$ uitnodiging om die eetsaal te inspekteer van die hand gewys en dit het tot ' $n$ boikot deur 600 verpleegsters en studentverpleegsters gelei (Critical Health, 1988:60)

In die laat tagtigerjare word politieke aspekte in die rasseverhoudingverslag aangespreek. Die "Race Relations Survey" (SAIRR, 1990:402) het dr. Venter, Minister van Gesondheid en Bevol. kingsontwikkeling, aangehaal waar sy beloof het dat alle vorme van rassediskriminasie in verpleging geïdentifiseer sou word en "everything possible will be done to institute corrective measures". Dr. Venter het daarop gewys dat salarisse van verpleegpersoneel ondersoek moes word, maar aangedui dat verskeie ander probleme ook indringend aandag moes geniet. Sy het onder andere beleidsake en die hantering van griewe as prioriteitareas vir aandag uitgesonder.

Tydens die vroeë negentigerjare was nywerheidsonrus in hospitale landwyd kenmerkend. Enkele insidente en gepaardgaande koerantberigte word weergegee.

In Januarie 1990 is elf assistentverpleegsters by die New King's Residentia 


\section{Kommunikasie is uiters belangrik vir alle deelnemers in arbeidsbetrekkinge.}

van onbetaamlike gedrag aangekla nadat hulle deelgeneem het aan ' $n$ "simpatiestaking" wat gespruit het uit twee ander assistente se afdanking. (Die twee is later her-indiens geneem, maar in die Arbeidsterapie-afdeling van die residensie geplaas). Ter verdediging van die elf word die volgende as versagtende omstandighede aan die dissiplinêre komitee van die SARV aangevoer, naamlik: "evidence had shown industrial relations practices at the New King's to be outdated. In addition, grievances brought to the management of the institution remained unresolved for years and there was salary discrimination on racial grounds" (Cape Times 90.01.19:3). In haar uitspraak het die voorsitter van die dissiplinêre komitee gesê dat verpleegsters tot veilige pasiëntsorg verbind is. Sy het ook die belang van gelukkige personeel wat hul potensiaal in hul beroep kon verwesenlik, beklemtoon en het die komitee aangemoedig om te versoek dat die SAVV ondersoek na die diensvoorwaardes by die tehuis sal instel.

Op 1 Februarie 1990 het 'n "staking" deur 200 swart verpleegassistente by die H.F. Verwoerd Hospitaal plaasgevind. Hulle griewe het ongelukkigheid oor diensvoorwaardes en buitengewoon swak salarisse ingesluit (Transvaler, 90.02.01:2).

Gedurende die tweede helfte van Februarie 1990 het hospitaalwerkers (Verpleegpersoneel uitgesluit) in die Kaapse skiereiland "gestaak". Vyt-entwintig hospitale en nagenoeg 5000 werkers was by hierdie 16 dae-lange "staking" betrokke. Vakbondbetrokkenheid en ' $n$ eis dat griewe op die hoogste vlak, naamlik deur Minister Venter self hanteer moes word, was kenmerkend van hierdie "staking". Hierdie insident het wye persdekking geniet en hieronder verskyn uittreksels van artikels wat ten tye van die "staking" gepubliseer is. "Die superintendent van die Grootte Schuur-hospitaal, Dokter Kane Berman, het nie die skuld vir die staking slegs voor die deur van die stakers gevee nie. Sy wys daarop dat daar reeds ' $n$ lang geskiedenis van gebrekkige onderhandelinge om hoër lone was en dat die outoriteite die gewig van die werkers se eise onderskat het" (Cape Times 90.03.07:1).

Hierdie blyk dus weereens 'n voorbeeld van oneffektiewe griewehantering deur die bestuur te wees. Die feit is verder onderstreep deur die vakbondverteenwoordigers se verklaring dat slegs onderhandelinge op die hoogste vlak hulle tevrede sou stel. "The Health Worker's Union wants to negotiate directly with people who can meet our demands directly like government ministers concerned and the commission of administration." In die berig is beweringe van mnr. K. Meiring, die Kaapse Administrateur, dat die KPA altyd gewillig was om na die griewe van die werkers te luister, en dit vir oorweging aan hoër gesag voor te lê, deur die vakbond ontken. "For the past four years workers have been raising grievances through the correct channels, only to be met with no response" (Argus, 90.03.09:1).

'n Afgetrede regter, mnr. $C$ van $Z y l$, is aangewys om as bemiddelaar met die werkers in gesprek te tree oor hulle griewe, maar die vakbond het hul wantroue in die stelsel uitgespreek deur die volgende uitlating: "He has no authority, he can only pass on our demands to a higher level. Over the past few years workers have been raising their grievances with local management and these have been passed on and nothing has been done, said a spokesman for the workers" (Argus, 90.03.12:3). Hier word 'n ooreenkoms met die Baragwanathinsident getoon waar daar ook belowe is om die griewe aan die hoër gesag oor te dra. Uiteindelik is niks gedoen om die griewe op te los nie en geen kommunikasie het met die werkers plaasgevind nie.

Kommunikasie is uiters belangrik vir alle deelnemers in arbeidsbetrekkinge. Dat diè vir gesondheidswerkers baie belangrik is, word duidelik geillustreer wanneer 'n segsman sê: "Working conditions in our hospitals have deteriorated steadily over recent years, with staff shortages and a steadily increasing patient load. Inflation has led to financial hardship, and many workers find they can no longer manage on their salaries. Some categories of workers are barred from becoming members of permanent staff, even after three or four decades of service, and do not qualify for pensions. There are fourteen Ministers of Health in this country - not one communicates effectively" (Cape Times, 90.03.09:1)

Te midde van hierdie arbeidsonrus het die toenemende tekort aan verpleegper- soneel aandag geniet. Daar is gewaarsku dat dit erger afmetings sou kon aanneem as gevolg van onopgeloste griewe. Die uitvoerende bestuurder van die SAW het ' $n$ vertoë tot die Minister van Gesondheid gerig om dringend aandag aan die beroep se werkstoestande en salarisse te skenk. Sy het daarop gewys dat meer as 32000 nuwe verpleegsters voor die jaar 2000 moet kwalifiseer om aan die land se behoefte te voldoen. Die bestaande tekort in die beroep maak dit noodsaaklik om te voorkom dat meer verpleegsters die beroep verlaat (Transvaler, 90.03.09:6). Hierdie geldige kommer word bevestig deur ' $n$ artikel in die Cape Times (90.03.15:2) waarin daar op ' $n$ moontlike uittog van verpleegsters uit die beroep gewys word, indien hulle finansiële griewe nie aangespreek sou word nie: "Another $20 \%$ of South Africa's nurses could leave the profession over the next few months if today's budget did not address their grievances, the Westerna Province branch of SANA said yesterday" is die opskrif van die berig wat ook effektiewe griewehantering in belang van personeelbehoud aanspreek.

Natal het soortgelyke griewe as die ander provinsies in verpleging ondervind en professionele verpleegkundiges het gedreig om ook aan "stakings" deel te neem. Sterk gevoelens van negatiwiteit is gelug en verpleegsters is in koerantberigte soos volg aangehaal: "nurses are all angry and aggressive desperate situations call for desperate measures and we are fully prepared to strike" (Natal Mercury, 90.03.17:6).

Ook in ander areas van hospitaalbestuur het ontevredenheid met die hantering van griewe op hoë vlak geblyk. Die voorsitter van die Nasionale Hospitaalsubkomitee, mnr. A Farred, is aangehaal dat hy sou gesê het dat sy unie al die afgelope 13 jaar probeer om hospitaalwerkers se griewe aan die regering voor te lê (Rapport, 90.03.18:1). 'n Berig wat daarop gedui het dat die komitee van die Staatsdiensliga met dr. R Venter - die Minister van Gesondheid en Bevolkingsontwikkeling - samesprekings gevoer het, beklemtoon hierdie gevoel van ontevredenheid. Die komitee het verklaar dat "dit kom voor of die Regering na herhaaldelike vertoë, versoeke en samesprekings van die afgelope 13 jaar, nie eintlik opreg was in onderhandelinge nie. Ons is hoopvol dat die nuwe samesprekings nuwe hoop sal bring" 

in Verteen-woordiger van die Health Workers Union is aangehaal: "The director of Provincial Hospital Services was presented with a list of health workers' demands 16 months before the hospital strike began. In November 1988 the workers committee at Grootte Schuur met dr. George Watermeyer and presented him with a list of demands. $\mathrm{He}$ promised to investigate the situation but we heard no more and issued him with the new demands two weeks before calling the strike. We indicated that if his response was unsatisfactory we would initiate strike action" (Cape Times, 90.03.24:5). Gebrekkige kommunikasie van die bestuur met die werkers, soos deur laasgenoemde voorbeeld aangedui word, blyk ' $n$ bydraende faktor te wees.

In Port Elizabeth is die Livingstonehospitaal vir meer as twee ure tot stilstand gebring, terwyl personeel, waaronder verpleegsters en geneeshere, aan 'n protesoptog deelgeneem het waartydens geëis is dat aandag aan hulle griewe gegee moes word. Die mediese superintendent, dr. G. White, het met die gegriefdes gesimpatiseer en sy kommer oor die situasie uitgespreek (Evening Post, 90.03.16:2).

Bogenoemde dui op ' $n$ nasionale ontevredenheid met betrekking tot griewehantering in verpleging en gesondhiedsdienste. Die haglikheid van die landwye situasie is deur die Demokratiese Party se LP vir Grootte Schuur, me. D Smuts, geskilder deurdat sy aangedui het dat $80 \%$ van die verpleegsters wat vier jaar opleiding ontvang het teen 'n geskatte koste van R16 000 per jaar, die dienste verlaat binne die eerste drie jaar nadat hulle hul opleiding voltooi het. Om dit te vererger, was $20 \%$ van verpleegposte in hospitale landwyd vakant. Sy het voortgegaan en die invloed van die swak werksomstandighede op die verpleegkundige geskets: "she is overworked, she is demoralised, she has to moonlight in her already limited time-off to supplement her income - and crucially, she is not getting the professional satisfaction which motivates modern working women. Listen to the demands of the nurse; when they say that some of the major effects of the nursing shortage are felt at the clinical level they are say-ing more than that patients suffer, that mistakes with medico I e g a l implications b e c o m e inevitable, that they themselves suffer burn-out and exhaustion. They are also saying that they cannot

spesiale vergadering en sprake van 'n sloerstaking gelei. Dr J Kruger, Uitvoerende Direkteur van Hospitaalwese in die Vrystaat, het aangedui dat klagtes ondersoek is: "Hulle kla oor sleutels vir hul kamers, die toestand van die terrein by die tehuis, die kos, toelating van mans en familie in hul kamers en diefwering op die tweede verdieping van die tehuis (Volksblad, 90.05.03:2).

Die ooreenkoms tussen griewe by die onderskeie hospitale, asook die ooreenkoms in gebrekkige hantering van griewe deur bestuur, is opvallend uit die beriggewing. Die vraag ontstaan of onopgeloste griewe van die verlede nie die teelaarde geskep het vir die onprofessionele gedrag van verpleegsters, om daardeur bestuur te dwing om aandag aan hulle griewe te skenk nie.

Hier word die kommerwekkende aan verpleegkundiges gekoppel aan die gebrekkige hantering of erkenning van griewe. Hierdie aanklag dat daar nie na die griewe van verpleegsters geluister word nie, word vanuit verskeie oorde in die literatuur gemaak. Alhoewel alle kommentaar nie ewe negatief is nie, word die effektiewe hantering van griewe selfs deur die hoopvolles as voorvereistes vir die opheffing van die krisis in verpleging gestel. Die Pretoria News (90.04.09:2) berig: "A senior member of the medical faculty at the University of Pretoria, who asked not to be named, says that if appropriate action in response to nurses' grievances is taken quickly, the profession has a bright future in South Africa." In dieselfde berig word ' $n$ voormalige lid van die opposisie in die ou Transvaalse Provinsiale Raad, mnr D Gibson, aangehaal: "Mr. Gibson says a nursing crisis was already developing when he was elected to serve on the Provincial Council twenty years ago." In enige beroep sou dit onaanvaarbaar wees dat daar reeds so lank sprake van ' $n$ krisis is sonder om daadwerklik na ' $n$ antwoord te soek. Dit blyk duidelik dat daar ' $n$ behoefte bestaan aan kommunikasie tussen verskillende vlakke van verpleegsters, en veral ook aan die effektiewe hantering van griewe. Insoverre dit effektiewe hantering van griewe aangaan, loop die uurglas vinnig leeg vir topbestuur en verpleegdiens-bestuurders om hul verant-woordelikheid teenoor die beroep en ondergeskiktes na te kom.

Bloemfontein se verpleegdienste was ook deur 'n soorgelyke krisis bedreig. Ontevredenheid onder die 400 leerling- en opgeleide verpleegsters in die swart en bruin verpleegsterstehuis by die Pelonomi-hospitaal by Bloemfontein, het tot ' $n$
By die Baragwanath-hospitaal het in 1990 weer 'n "staking" van groot omvang voorgekom, met die gevolg dat pasiënte ontslaan moes word al was hul nog nie gesond nie. Dit is kommerwekkend dat die pasiënte weereens die lydende partye was. Die werkers en verpleegpersoneel het gevoel dat hul griewe steeds verontagsaam word. Hierdie gevoel word in die volgende aanhaling weerspië̈l: "Strikes have now become commonplace as workers down tools, saying: 'Enough is enough'. This is happening again. Instead of addressing worker grievances, the superintendent, Dr. Chris van den Heevers, is threatening to close down the hospital. This is putting physiological pressure on the striking worker" (Sowetan, 90.05.05:6). Vyt jaar het verloop sedert die insident waar die afgedankte "stakende" werkers herindiens geneem is weens die hofsbeslissing dat die griewe van die werkers nie aangespreek is nie. Nou blyk dit weereens dat die verontagsaming van griewe deur dieselfde bestuur herhaal word

Die Suid-Afrikaanse Raad op Verpleging (SARV) wat die professionele standaarde van die professie bewaak, het sy misnoë oor die onprofessionele gedrag van die verpleegsters uitgespreek en daarop

Wanneer konflik aanvaar word as ' $n$ onafwendbare element in die werkplek, is dit noodsaaklik dat verpleegkundiges reeds vanaf hulle studentejare leiding gedrag. ontvang in selfhandhawende 
gewys dat dit die beroep in diskrediet bring. ' $n$ Artikel "The right of a nurse to strike" (Sunday Star, 90.05.06:4) haal 'n verteenwoordiger van die SARV aan wat die landwye "stakings" kritiseer: "This lack of care for the wellbeing of their patients brings discredit to everything the nursing profession stands for."

Uit die geledere van ' $n$ ander professionele vereniging het daar egter steun vir die optrede van die verpleegkundiges gekom. Max Price, verteenwoordiger van NAMDA (National Medical and Dental Association) sê: "The opposite is true; when nurses demand an improvement in their working conditions they do so because they are also interested in the long-term quality of care in the health services. In the past the only option open to nurses was to resign and that was why so many had left the profession. Industrial action is constructive because the grievances are articulated and presented to the authorities. If nurses simply resign, one at a time, the real problems are never identified" (SAIRR, 1990:65). Hierdie teenstrydige standpunte van professionale verantwoordelikheid teenoor die pasiënt versus die reg om arbeid te weerhou in ' $n$ poging om bestuur te dwing om aandag aan die griewe van werkers te skenk, behoort aandag te geniet. Indien daar gekyk word na die krisis in die verpleegberoep en die aantal verpleegkundiges wat die beroep verlaat het, soos aangedui deur die SAVV. verslag van die ondersoek na hierdie krisis (Muller \& Coetzee, 1990), is dit moontlik dat bedanking as enigste opsie gesien is. Die navorser huldig die mening dat indien werkstevredenheid by personeel, asook die behoud van personeel deur bestuur hoog aangeskryt word, die basiese beginsels van griewehantering gehandhaaf sal word. Konflik sal dus hanteer word voor dit tot sulke ekstreme gedrag aanleiding gee. Wanneer konflik aanvaar word as ' $n$ onafwendbare element in die werkplek, is dit noodsaaklik dat verpleegkundiges reeds vanaf hulle studentejare leiding ontvang in selfhandhawende gedrag. Die griewe-prosedure sal dan slegs gesien word as ' $n$ instrument waardeur ' $n$ grief objektief maar ferm onder die aandag van bestuur gebring kan word, en nie as 'n politieke verhoog nie.

\section{Gevolgtrekkings}

Die formalisering van griewe in verpleging hou met die totstandkoming van hospitale in Suid-Afrika veband. Die eerste amptelike grief gaan oor personeeltekorte in verpleging asook ' $n$ gebrek aan gesag, en is in 1824 aanhangig gemaak deur die inwonende chirurg van die Somerset-hospitaal. Deur die jare is daar aanduidings dat dieselfde faktore lei tot griewe by verpleegpersoneel, naamlik swak werksomstandighede, ontoereikende salarisse, ontevredenheid met die kos wat aan verpleegpersoneel verskaf is, burokratiese bestuurstyl by bestuur, en te streng reëls wat geld in verpleegsterstehuise. Politisering van gesondheids-dienste het ook as faktor na vore gekom en die invloed van die implementering van die bevindinge van die Wiehahn-kommissie sedert die laat sewentiger is duidelik merkbaar in verpleging. Sedert die tagtigerjare maak verpleegkundiges gebruik van "stakingsaksies" as uitdrukking van hul onvergenoegdheid met die hantering van griewe in hospitale.

Die spesifieke gevolgtrekkings word gedoen aan die hand van die bevindinge van die navorser met behulp van die literatuur en die gegewens verkry uit die koerantanalise.

1 Daar bestaan griewe in verpleging vandat die eerste hospitaal gebou is tot vandag.

2 Die eerste amptelike grief is in 1824 deur ' $n$ chirurg ingedien.

3 Griewe kom hoofsaaklik voor in die area van werksomstandighede, vergoeding en bestuur.

4 Ontevredenheid oor salarisse en kos is in 1869 deur verpleegsters ingedien.

$5 \quad$ Alhoewel griewe deur personeel bekend gemaak word aan bestuur, word dit dikwels geïgnoreer.

6 Verpleegdiensbestuurders blyk nie vaardig in die hantering van griewe te wees nie en dieselfde foute word herhaal in dieselfde hospitale. So is bykans identiese griewe wat in Baragwanathhospitaal tot die staking van 1985 gelei het, in 1990 weer byna identies deur bestuur hanteer

7 Ontevredenheid met die oneffektiewe hantering van griewe gee aanleiding tot industriële aksie deur verpleegpersoneel reeds sedert 1889.

\section{Aanbevelings}

Die verpleegdiensbestuurder is aanspreeklik vir effektiewe personeelbestuur waarvan griewehantering ' $n$ belangrike komponent vorm. Deurlopende en volgehoue bemagtiging van die verpleegdiensbestuurder in die effektiewe hantering van griewe in ' $n$ verpleegdiens word aanbeveel, asook die ontwikkeling van ' $n$ model vir die hantering van griewe in verpleegdienste.

\section{Verwysings}

ARGUS, 18 April 1980: 7, col .2: Poor pay rise for nurses.

ARGUS 9 March 1990: 1, col. 1: 5500 as strike action hits 18 hospitals.

ARGUS 12 March 1990: 1, col. 3: More nurses threaten to strike.

BURGER 4 Maart 1990: 1, kol.1: Stakings by Kaapse hospitale kritiek.

BURGER 20 Maart 1990: 4, kol.2: Minister, werkers gou byeen.

BURNS, N \& GROVE, SK 1987. The practice of nursing research. Conduct, critique and utilization. Philadelphia: WB Saunders

CAPE TIMES 19 January 1990: 3, col. 1: Strike at New Kings Residentia.

CAPE TIMES 7 March 1990: 5, col. 1: Nine city hospitale hit by strike.

CAPE TIMES 9 March 1990: 7, col. 2 : Poor communication by authorities.

CAPE TIMES 15 March 1990: 2, col. 1: Another $20 \%$ of South Africa's nurses could leave the profession over the next few months if today's budget did not address their grievances.

CAPE TIMES 24 March 1990: 5, col.1: $80 \%$ of nurses "quit work in 3 years".

CITIZEN 26 Nvember 1985: 3, col.1: Baragwanath: Students back.

CRITICAL HEALTH 1988: Editorial Collective. Nr. 24. Johannesburg: Doornfontein

DENTON, DK \& BOYD, C 1990. Employee complaint handling. Tested techniques for human resource managers. New York: Quorum Books.

EVENING POST 16 March 1990: 2, col. 2: Natal nurses threaten to participate in strike.

HAT 1988: Verklarende handwoordeboek van die Afrikaanse taal. Kaapstad: Perskor Uitgewery.

MEDICINE AND PHARMACY ACT 1891: No. 34 of 1891.

MULLER, ME \& COETZEE, L 1990. Verslag oor die ondersoek na die verpleegberoep. Pretoria: SuidAfrikaanse Verpleegstersvereniging. 
NATAL MERCURY 17 MARCH 1990:

6, col.1: Natal nurses threaten to participate in strike.

NUA 100-L 1992: Enigste studiegieds vir NUA 100-L. Pretoria: UNISA.

PRETORIA NEWS 9 April 1990: 2, col.2: Nursing crisis: TPA labelled "incompetent".

RAPPORT 18 Maart 1990: 1, kol.1: Minister ernstig oor krisis.

SOUTH AFRICAN INSTITUTE OF RACE RELATIONS 1982: Race Relations Survey 1982. SAIRR: Johannesburg.

SOUTH AFRICAN INSTITUTE OF RACE RELATIONS 1990: Race relations survey 1989/1990. SAIRR: Johannesburg.

SCOTT, J 1990. A matter of record. Cambridge: Polity Press.

SEARLE, C 1965. A history of the development of nursing in South Africa (1652-1960): a socio-historical survey. Pretoria: South African Nursing Association.

SEARLE, C 1987. Professionele praktyk: 'n Suid-Atrikaanse verpleegperspektief. Durban: Butterworths.

SOWETAN, 28 November 1985: 38, col. 1-3: Baragwanath: What was really achieved?

STAR, 26 November 1985: 12, col. 2: Hear this.

STAR, 29 November 1985: 16, col. 1-2: Analysing the anatomy of a hospital strike.

SUNDAY STAR, 5 May 1990: 4: The right of a nurse to strike.

TRANSVALER, 1 Februarie 1990: 2 , kol.1: Staking by HF

TRANSVALER, 9 Maart 1990: 6, kol. 1: 32000 verpleegsters nodig.

VOLKSBLAD, 3 Mel 1990: 2, kol. 1-2: Hoës bespreek probleme by Pelonomi.

WET OP VERPLEEGSTERS 1944: Wet no. 45 van 1944. Pretoria. 